\title{
Association of C677T MTHFR and G20210A FII prothrombin polymorphisms with susceptibility to myocardial infarction
}

\author{
WIAM HMIMECH $^{1 *}$, HIND HASSANI IDRISSI $^{1^{*}}$, BREHIMA DIAKITE $^{1}$, \\ DALILA BAGHDADI ${ }^{2}$, FARAH KORCHI ${ }^{2}$, RACHIDA HABBAL $^{2}$ and SELLAMA NADIFI $^{1}$ \\ ${ }^{1}$ Laboratory of Genetics and Molecular Pathology, Medical School, University Hassan II, Casablanca BP 9154; \\ ${ }^{2}$ Department of Cardiology, Ibn Rochd University Hospital Center, Casablanca 20102, Morocco
}

Received March 2, 2016; Accepted May 19, 2016

DOI: $10.3892 /$ br.2016.717

\begin{abstract}
Myocardial infarction (MI) is a common complex pathology, localized in the main leading causes of mortality worldwide. It is the result of the interaction of genetic and environmental factors. The aim of the present study was to investigate the potential association of C677T 5,10-methylenetetrahydrofolate reductase (MTHFR) (rs1801133) and G20210A factor II prothrombin (FII) (rs1799963) polymorphisms with the susceptibility of MI. Following extraction by the standard salting-out procedure, DNA samples of $100 \mathrm{MI}$ patients and 182 apparently healthy controls were genotyped by polymerase chain reaction-restriction fragment length polymorphism using HinfI and HindIII restriction enzymes, respectively. The results show a significant association of the G20210T FII polymorphism with the MI risk. The frequencies of the heterozygote genotype GA, homozygous mutated AA and the G20210A allele was higher among patients compared to controls (GA: 59 vs. $5.5 \%, \mathrm{P}<0.001$; AA: 10 vs. $0 \%$, $\mathrm{P}=0.003$; and 20210A: 39.5 vs. $2.7 \%, \mathrm{P}<0.003$ ), suggesting that this polymorphism may be a potential genetic marker for MI. No significant association was observed between the $C 677 T$ MTHFR and MI occurrence, and there was more heterozygote $\mathrm{CT}$ in the patient group compared to the controls. As a multifactorial disease, the development of MI may be the result of numerous factors that influence synergistically its occurrence.
\end{abstract}

Correspondence to: Miss Hind Hassani Idrissi, Laboratory of Genetics and Molecular Pathology, Medical School, University Hassan II, 19 Rue Tarik Ibnou Ziad, Casablanca BP 9154, Morocco E-mail: hassani-idrissi-hind@hotmail.fr

*Contributed equally

Abbreviations: MI, myocardial infarction; MTHFR, 5,10-methylenetetrahydrofolate reductase; $F I I$, factor II prothrombin; $\mathrm{CI}$, confidence interval; OR, odds ratio

Key words: myocardial infarction, susceptibility, association, Moroccan population, C677T MTHFR, G20210A FII
Thus, further studies are merited to try to better assess these associations (gene-gene and gene-environment interactions).

\section{Introduction}

According to the World Health Organization, every year $\sim 50$ million people succumb due to ischemic heart diseases, particularly myocardial infarction (MI), which is a worldwide leading cause of fatality (1). In general, MI is a result of myocardium necrosis, which occurs when the latter does not receive enough oxygen, due to a sudden occlusive thrombosis of the coronary artery that irrigates this section of myocardium (2).

Several studies have identified that genetic in addition to known risk factors (including age, gender, arterial hypertension, smoking, diabetes and dyslipidemia) strongly increases the risk of MI occurrence (3). Among the numerous genes that were previously found to be in association with MI susceptibility, 5,10-methylenetetrahydrofolate reductase (MTHFR) and factor II prothrombin $(F I I)$ genes are the most widely reported.

The MTHFR gene is located on chromosome 1 at the 'Ip36.3' position; the corresponding cDNA sequence comprises 11 exons spanning $2.2 \mathrm{~kb}$ (4). The main product of the MTHFR gene is a protein of $77 \mathrm{kDa}$ with catalytic activity, composed of 656 amino acids (5). It is involved in folate metabolism by catalyzing the irreversible conversion of 5,10-methylenetetrahydrofolate $\left(5,10-\mathrm{CH}_{2}-\mathrm{FH}_{4}\right)$ into 5-methyltetrahydrofolate (5- $\left.\mathrm{CH}_{3}-\mathrm{FH}_{4}\right)$, which is the major circulating form of folic acid and the cosubstrate for remethylation of homocysteine to methionine $(6,7)$.

In its 5-methyl form, folate participates in single carbon transfers that occur during nucleotide synthesis; S-adenosylmethionine formation; remethylation of homocysteine to methionine; and methylation of DNA, proteins, neurotransmitters and phospholipids (8).

The C677T allele of the MTHFR gene is the conversion of cytosine (C) to thymine (T) at position 677 , which results in a conversion of alanine to valine at the binding site of the flavin adenine dinucleotide, the cofactor of MTHFR enzyme (9). This allele is commonly known as 'labile'; it facilitates the separation of the enzyme from its cofactor, reducing the activity of the encoded enzyme at $\geq 37^{\circ} \mathrm{C}(10,11)$. Thus, if the folate intake is insufficient, the activity of the homozygote decreases 
by $50-60 \%$ at $37^{\circ} \mathrm{C}$, and by $65 \%$ at $46^{\circ} \mathrm{C}$; heterozygotes are in the intermediate range, and homozygotes tend to have slightly increased plasmatic homocysteine levels (10).

Prothrombin is a precursor of thrombin. It has an essential role in fibrin formation and coagulation procedure. Numerous studies have demonstrated that a single base-pair change in the prothrombin gene $(G 20210 A)$ is associated with increased plasma prothrombin levels (12-15); this has generated significant interest and it has been suggested that this polymorphism may lead to increased risks of arterial and venous thrombosis (16).

Located on chromosome 11 (11p11), in a 3'-untranslated region of the prothrombin gene, the $\mathrm{G} 20210 \mathrm{~A}$ variant replaces a single base of guanine $(G)$ with adenine $(A)$ at position 20210, where the pre-mRNA receives the poly A-tail (17). Patients with one copy of this polymorphism have $\sim 5$-fold greater risk of blood clot formation compared to patients without. The risk becomes 50 -fold higher among subjects with two copies of the $20210 A$ allele. In such conditions, they become prone to earlier or severe arterial and venous thrombosis, particularly with the addition of a family history of such events $(12,18,19)$.

Although mutation in the prothrombin gene has been frequently studied, data regarding this mutation to the risks of $\mathrm{MI}$ are limited and their interpretation has been controversial (13-15).

In the present study, the main aim was to investigate the association of the C677T and G20210A variants of MTHFR and FII prothrombin genes with MI among Moroccan patients.

\section{Materials and methods}

Patients. In the present study, 100 Moroccan MI patients were recruited from the Department of Cardiology (Ibn Rochd University Hospital Center, Casablanca, Morocco), in addition to 184 DNA samples of apparently healthy subjects from the DNA bank of the general population available in the Laboratory of Genetics and Molecular Pathology (Medical School, University Hassan II, Casablanca, Morocco). Written consent was obtained from all participants, and blood samples were collected into 4cc EDTA tubes and were stored at $-20^{\circ} \mathrm{C}$ or treated immediately. For the patients, genomic DNA was extracted from peripheral blood leukocytes using the salting-out procedure (20), and DNA was quantified using spectrophotometry. The study has been performed in accordance with the Declaration of Helsinki and has been approved by the ethics committee of The School of Medicine, Casablanca, Morocco.

Polymorphism analysis. C677T MTHFR and G20210A FII polymorphisms were analyzed using polymerase chain reaction and restriction fragment length polymorphism techniques, as respectively described by Frosst et al (21) and Danneberg et al (22). Following cleavage of amplified fragments using Hinf I and HindIII restriction enzymes, respectively, DNA bands were stained with ethidium bromide and visualized under ultraviolet light.

Statistical analysis. Statistical analyses were performed using SPSS software 21.0 (IBM Corp., Armonk, NY, USA). $\chi^{2}$ test was used to determine statistical significance of association/non-association between genotypes and clinical parameters. Hardy-Weinberg Equilibrium (HWE) test was
Table I. HWE for the C677T MTHFR and G20210A FII distributions among the cases and controls.

\begin{tabular}{llllll}
\hline & \multicolumn{2}{c}{ HWE cases } & & \multicolumn{2}{c}{ HWE controls } \\
\cline { 2 - 3 } Genotypes & $\chi^{2}$ & $\begin{array}{c}\text { P-value } \\
(\mathrm{P}>0.05)\end{array}$ & & $\chi^{2}$ & $\begin{array}{c}\text { P-value } \\
(\mathrm{P}>0.05)\end{array}$ \\
\hline C677T MTHFR & 1.65 & $0.43^{\mathrm{a}}$ & & 0.68 & $0.457^{\mathrm{a}}$ \\
G20210A FII & 5.5 & $0.06^{\mathrm{a}}$ & & 0.16 & $1^{\mathrm{a}}$ \\
\hline
\end{tabular}

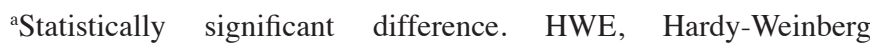
Equilibrium; MTHFR, 5,10-methylenetetrahydrofolate reductase; FII, factor II prothrombin.

performed in the cases and controls groups for the two polymorphisms analyzed. Odds ratio (OR) was calculated to estimate the association between genotypes and risk of $\mathrm{MI}$, using a confidence interval (CI) of $95 \%$, and $\mathrm{P}<0.05$ was considered to indicate a statistically significant difference.

\section{Results}

Patient characteristics. The study cohort consisted of $100 \mathrm{MI}$ patients and 182 apparently healthy controls. The distributions of C677T MTHFR and G20210A FII polymorphisms were in HWE in the case and control groups (Table I). The average age of patients was $58.60 \pm 2.17$ years, and $66 \%$ of them were $>50$ years of age with a male predominance $(70$ males vs. 30 females).

Correlation analysis for the polymorphisms. Among the seven risk factors analyzed in the study, C677T MTHFR was positively correlated with obesity $(\mathrm{P}=0.02)$. No correlation was observed between G20210A FII with any one of these risk factors (Table II).

For the C677T MTHFR polymorphism, the genotypic and allelic frequencies were 38, 52 and $10 \%$, respectively, for the CC, CT and TT genotypes, and 64 and 36\%, respectively, for the $677 \mathrm{C}$ and $677 \mathrm{~T}$ alleles among the cases. In the control group, the frequencies were 52.2, 41.8 and $6 \%$, respectively, for the CC, CT and TT genotypes, and 73.1 and $26.9 \%$, respectively, for the $677 \mathrm{C}$ and $677 \mathrm{~T}$ alleles (Table III).

For the G20210A FII variant, the genotypic and allelic frequencies among the cases were 31,59 and $10 \%$, respectively, for the GG, GA and AA genotypes, and 60.5 and $39.5 \%$, respectively, for the $20210 G$ and $20210 A$ alleles. Among the healthy controls, $94.5 \%$ were homozygous for the $20210 \mathrm{G}$ allele. The 20210A allele was absent in the homozygous form (0\% AA), and only $5.5 \%$ carried one copy of it (GA). Allelic frequencies were $97.3 \%$ for the $20210 \mathrm{G}$ allele vs. $2.7 \%$ for the 20210A allele (Table III).

No statistically significant association was observed between the C677T MTHFR polymorphism and MI risk [CT: $\mathrm{OR}=1.71$ (95\% CI, 1.02-2.84), $\mathrm{P}=0.61$; TT: OR=2.27 (95\% CI, 0.88-5.82), $\mathrm{P}=0.64$; and 677T: $\mathrm{OR}=1.35$ (95\% CI, 0.89-2.03), $\mathrm{P}=0.75]$, suggesting that even patients carrying at least one copy of the $677 \mathrm{~T}$ allele are not protected and this variant may not be a genetic risk factor for MI susceptibility in Morocco. 
Table II. Distribution of C677T MTHFR and G20210A FII polymorphisms according to risk factors among MI patients.

\begin{tabular}{|c|c|c|c|c|c|c|c|c|c|}
\hline \multirow[b]{2}{*}{ Risk factors } & \multirow[b]{2}{*}{ Patients, $n(n=100)$} & \multicolumn{3}{|c|}{$M T H F R, \mathrm{n}(\%)$} & \multirow[b]{2}{*}{ P-value } & \multicolumn{3}{|c|}{$F I I, \mathrm{n}(\%)$} & \multirow[b]{2}{*}{ P-value } \\
\hline & & $\mathrm{CC}$ & $\mathrm{CT}$ & $\mathrm{TT}$ & & GG & GA & AA & \\
\hline \multicolumn{10}{|l|}{ Age, years } \\
\hline$\leq 50$ & 34 & $13(38.23)$ & $19(55.88)$ & $2(5.89)$ & 0.36 & $13(38.23)$ & $18(52.94)$ & $3(8.83)$ & 0.53 \\
\hline$>50$ & 66 & $25(37.87)$ & $33(50.00)$ & $8(12.13)$ & & $18(27.27)$ & $41(62.12)$ & $7(10.61)$ & \\
\hline \multicolumn{10}{|l|}{ Gender } \\
\hline Male & 70 & $30(42.85)$ & $34(48.57)$ & $6(8.58)$ & 0.33 & $22(31.42)$ & $44(62.85)$ & $4(5.73)$ & 0.1 \\
\hline Female & 30 & $8(26.67)$ & $18(60.00)$ & $4(13.33)$ & & $9(30.00)$ & $15(50.00)$ & $6(20.00)$ & \\
\hline \multicolumn{10}{|l|}{ HTA } \\
\hline Presence & 44 & $16(36.37)$ & $25(56.81)$ & $3(6.82)$ & 0.46 & $11(25.00)$ & $28(63.63)$ & $5(11.37)$ & 0.5 \\
\hline Absence & 56 & $22(39.28)$ & $27(48.21)$ & $7(12.51)$ & & $20(35.71)$ & $31(55.35)$ & $5(8.94)$ & \\
\hline \multicolumn{10}{|l|}{ Diabetes } \\
\hline Presence & 39 & $10(25.64)$ & $25(64.10)$ & $4(10.26)$ & 0.12 & $8(20.51)$ & $27(69.23)$ & $4(10.26)$ & 0.17 \\
\hline Absence & 61 & $28(45.90)$ & $27(44.26)$ & $6(9.84)$ & & $23(37.70)$ & $32(52.45)$ & $6(9.85)$ & \\
\hline \multicolumn{10}{|l|}{ Smoking } \\
\hline Presence & 45 & $19(42.22)$ & $22(48.88)$ & $4(8.89)$ & 0.49 & $13(28.89)$ & $29(64.44)$ & $3(6.66)$ & 0.47 \\
\hline Absence & 55 & $19(34.54)$ & $30(54.54)$ & $6(10.92)$ & & $18(32.72)$ & $30(54.54)$ & $7(12.74)$ & \\
\hline \multicolumn{10}{|l|}{ Obesity } \\
\hline Presence & 22 & $8(36.36)$ & $8(36.36)$ & $6(27.28)$ & $0.02^{\mathrm{a}}$ & $7(31.81)$ & $12(54.54)$ & $3(13.65)$ & 0.79 \\
\hline Absence & 78 & $30(38.46)$ & $44(56.41)$ & $4(5.13)$ & & $24(30.76)$ & $47(60.25)$ & $7(8.99)$ & \\
\hline \multicolumn{10}{|l|}{ Dyslipidemia } \\
\hline Presence & 27 & $8(29.63)$ & $16(59.26)$ & $3(11.11)$ & 0.59 & $9(33.33)$ & $15(55.55)$ & $3(11.12)$ & 0.9 \\
\hline Absence & 73 & 30 (41.09) & $36(49.31)$ & $7(9.59)$ & & $22(30.13)$ & $44(60.27)$ & $7(9.59)$ & \\
\hline
\end{tabular}

${ }^{\mathrm{a}} \mathrm{P}<0.05$. MTHFR, 5,10-methylenetetrahydrofolate reductase; FII, factor II prothrombin; HTA, arterial hypertension.

Table III. C677T MTHFR and G20210A FII polymorphism frequencies and genetic distribution among the cases and controls.

\begin{tabular}{|c|c|c|c|c|c|}
\hline Genes & Genotypes & Cases, $\mathrm{n}(\%)(\mathrm{n}=100)$ & Controls, $\mathrm{n}(\%)(\mathrm{n}=182)$ & OR $(95 \% \mathrm{CI})$ & $\mathrm{P}$-value $(\mathrm{P}<0.05)$ \\
\hline \multirow[t]{5}{*}{$M T H F R$} & $\mathrm{CC}$ & $38(38.0)$ & $95(52.2)$ & Ref & \\
\hline & CT & $52(52.0)$ & $76(41.8)$ & $1.71(1.02-2.84)$ & 0.61 \\
\hline & TT & $10(10.0)$ & $11(6.0)$ & $2.27(0.88-5.82)$ & 0.64 \\
\hline & $\mathrm{C}$ & $128(64.0)$ & $171(73.1)$ & Ref & \\
\hline & $\mathrm{T}$ & $72(36.0)$ & 87 (26.9) & $1.35(0.89-2.03)$ & 0.75 \\
\hline \multirow[t]{5}{*}{$F I I$} & GG & $31(31.0)$ & $172(94.5)$ & Ref & \\
\hline & GA & $59(59.0)$ & $10(5.5)$ & $32.73(15.11-69.71)$ & $<0.001^{\mathrm{a}}$ \\
\hline & AA & $10(10.0)$ & $0(0.0)$ & $115(1.75-7332)$ & $0.003^{\mathrm{a}}$ \\
\hline & $\mathrm{G}$ & $121(60.5)$ & $182(97.3)$ & Ref & \\
\hline & A & $79(39.5)$ & $0(2.7)$ & $238.83(4.48-12581.7)$ & $<0.001^{\mathrm{a}}$ \\
\hline
\end{tabular}

${ }^{\mathrm{a}} \mathrm{P}<0.05$. MTHFR, 5,10-methylenetetrahydrofolate reductase; FII, factor II prothrombin; OR, odds ratio; CI, confidence interval.

By contrast, the G20210A FII polymorphism was highly associated with $\mathrm{MI}$ risk among patients carrying even a single or double copy of the $20210 \mathrm{~A}$ allele [P-value (GA) $<0.001$ and $\mathrm{P}$-value $(\mathrm{AA})=0.003)]$ (Table III). These findings suggest that this variant may be a potential genetic marker for MI in Moroccan population.

\section{Discussion}

With a complex pathology, numerous factors are involved in the occurrence of MI. In interaction with environmental factors, the genetic background has an essential role in MI susceptibility. A number of studies began, over the few past 
years, focusing on the implication of hemostatic markers in MI development, and have suggested that numerous genes affecting coagulation proteins are prothrombotic risk factors $(23,24)$, among which are the FII (G20210A variant) and MTHFR (C677T variant) genes.

Several studies have investigated the association of prothrombotic genetic markers, including FII and MTHFR genes with MI risk, but have provided divergent and inconclusive results $(5,25,26)$.

To the best of our knowledge, this is the first study to explore the potential association of the G20210A FII and C677T MTHFR polymorphisms with MI risk in the Moroccan population.

In the present study sample, the majority of patients were $>50$ years of age $(66 \%)$ and were predominantly male (70 vs. $30 \%$ who were female). This was in agreement with the Croatian study by Jukic et al (27) regarding the implication of the ABO blood group genotypes and the prothrombotic mutations of factor V Leiden, prothrombin G20210A FII and MTHFR C677T on MI occurrence. The study noted that $75.3 \%$ of the patients recruited were $>55$ years of age, with a male predominance ( 63.2 male vs. $36.8 \%$ female). In addition, the same study reported that males had a 1.5 -fold greater risk of developing MI compared to females $(\mathrm{P}<0.05)$, and that older age patients ( $>55$ years) had $>20$-fold greater risk ( $\mathrm{OR}=21.1$; 95\% CI, 12.64-35.23).

Hyperhomocysteinemia is known to be an important risk factor for cardiovascular diseases, such as MI. The C677T polymorphism of MTHFR gene has been associated with decreased MTHFR enzyme efficiency and its thermolability (28). Previous studies have reported that individuals carrying a double copy of the $677 \mathrm{~T}$ allele had significantly increased plasma levels of homocysteine, and suggested that this variant may be a potential genetic risk factor for cardiovascular diseases (29-31).

According to the present data, the C677T MTHFR variant was significantly associated to obesity $(\mathrm{P}=0.02)$ (Table II). The CT genotype was the most frequent among patients (52\%) compared to the other genetic profiles (38\% CC and $10 \% \mathrm{TT})$. In healthy controls, the CC genotype was the most frequent $(52.2 \%)$ vs. 41.8 and $6 \%$ for the CT and TT genetic profiles, respectively. Similar findings were reported by Spiroski et al (32), which found that the CT genotype was the most frequent genotype among patients $(51.3 \%)$ vs. $35.5 \% \mathrm{CC}$ and $13.2 \% \mathrm{TT}$. According to this study, the T allele frequency was higher in patients compared to controls, which consists with the present findings ( $\mathrm{T}$ allele frequency in patients group was $36 \%$ compared to $26.9 \%$ among healthy controls).

Other studies reported that the higher frequency of homozygous mutated genotype TT (18-19\%) was found in the Italian population $(29,33,34)$. It was $16.7 \%$ in Greece, $6.2 \%$ in Germany and 6\% in Croatia $(35,36)$. Xuan et al $(37)$ reported that the $677 \mathrm{~T}$ allele frequency was $28.99 \%$ in Caucasian children vs. $42.28 \%$ in Asian pediatric patients, and $31.76 \%$ in the Caucasian maternal vs. $41.51 \%$ in the Asian maternal population.

Regarding the present results, no statistically significant association was observed between the C677T MTHFR polymorphism and MI risk in Morocco. Numerous studies have investigated this association among different populations and have noted similar findings (38-43). Other studies suggest a significant association of C677T MTHFR with MI risk $(30,37,44,45)$.

The G20210A polymorphism of the FII prothrombin gene is correlated with higher plasma levels of prothrombin among subjects carrying this variant compared to normal subjects, making them prone to blood clots and thrombotic events $(13,19,46,47)$. Regarding the biology, high plasma concentrations of prothrombin associated with the presence of the G20210A FII polymorphism may confer an elevated risk for cardiovascular disease (48).

The present results show that no genetic profile was the most frequent in the patient group compared to the controls, and no statistically significant association of the G20210A FII polymorphism with any one of the risk factors analyzed was observed. There was more heterozygote genotype (GA) among patients compared to the healthy controls (59 and 5.5\%, respectively). Consistent results were reported by Ercan et al (48) among the Turkish population, and even the heterozygote exhibited a significant association of the G20210A FII polymorphism with coronary artery disease risk.

According to the present data, the homozygous mutated genotype (AA) frequency was $10 \%$ among patients and $0 \%$ among controls. The $20210 \mathrm{~A}$ allele frequency was higher in the patient group (39.5\%) compared to the control group (2.7\%). The study performed by Ercan et al (48) reported similar results among healthy controls, signaling that the homozygous mutated profile of G20210A FII polymorphism was absent in the control group. The study also reported that this genotype was not detected among patients. Other similar findings were reported by Doggen et al (14), signaling that the $20210 \mathrm{~A}$ allele was present in only $2 \%$ of healthy controls, and suggesting that the G20210A FII polymorphism is associated with the risk of venous thromboembolism (OR=2.8). In 2009, Gohil et al (49) reported that this variant was correlated the venous thromboembolism risk $(\mathrm{OR}=3.2)$, and that the risk associated with the homozygous genetic profile of the polymorphism was 6.7-fold higher.

The present results show that the G20210A polymorphism of the FII prothrombin gene was significantly associated with susceptibility to MI.The results of the previous studies regarding this association remain inconsistent $(14,15,20,48,50-55)$.

The divergences in results regarding the association of C677T MTHFR and G20210A FII variants with MI risk may be explained by numerous factors, such as differences in genetic background among the studied populations; differences in the selection of patients and controls; studies sample sizes and ethnicity.

In conclusion, to the best of our knowledge this is the first study to evaluate the association of C677T MTHFR and G20210A FII prothrombin polymorphisms with MI in Morocco. According to the data, no significant association was observed between the C677T MTHFR variant and MI risk. The heterozygote genetic profile $(\mathrm{CT})$ was more frequent among patients compared to the controls. By contrast, the G20210A FII variant was significantly correlated to MI risk, with a predominance of the heterozygote genotype (GA) and the high frequency of the 20210A allele among patients compared to the controls, thus suggesting that this polymorphism may be a potential genetic marker for MI in 
Morocco. As a multifactorial disease, the development of MI may be synergistically influenced by numerous factors at different intensities. Thus, further investigations are required to assess these associations in greater detail (gene-gene and gene-environment interactions).

\section{Acknowledgements}

The authors would like to thank all the staff of the Laboratory of Genetic and Molecular Pathology and the Department of Cardiology for their collaboration and help.

\section{References}

1. Lopez E and Jamison M: Global Burden of Disease and Risk Factors: Disease Control Priorities Project. World Bank and Oxford University Press, New York, NY, 2006.

2. Davies MJ and Thomas AC: Plaque fissuring - the cause of acute myocardial infarction, sudden ischaemic death, and crescendo angina. Br Heart J 53: 363-373, 1985.

3. Sakowicz A, Fendler W, Lelonek M and Pietrucha T: Genetic variability and the risk of myocardial infarction in Poles under 45 years of age. Arch Med Sci 6: 160-167, 2010.

4. Goyette P, Pai A, Milos R, Frosst P, Tran P, Chen Z, Chan M and Rozen R: Gene structure of human and mouse methylenetetrahydrofolate reductase (MTHFR). Mamm Genome 9: 652-656, 1998.

5. Rozen R: Genetic predisposition to hyperhomocysteinemia: Deficiency of methylenetetrahydrofolate reductase (MTHFR) Thromb Haemost 78: 523-526, 1997.

6. Kutzbach C and Stokstad EL: Mammalian methylenetetrahydrofolate reductase. Partial purification, properties, and inhibition by S-adenosylmethionine. Biochim Biophys Acta 250: 459-477, 1971

7. Ma J, Stampfer MJ, Giovannucci E, Artigas C, Hunter DJ, Fuchs C, Willett WC, Selhub J, Hennekens CH and Rozen R: Methylenetetrahydrofolate reductase polymorphism, dietary interactions, and risk of colorectal cancer. Cancer Res 57: 1098-1102, 1997

8. Rosenblatt DS: Inherited disorders of folate transport and metabolism. In: The Metabolic and Molecular Bases of Inherited Disease. Scriver CR, Beaudet AL, Sly WS and Valle D (eds). McGraw-Hill Inc., New York, NY, pp3111-3128, 1995.

9. Skibola CF, Smith MT, Kane E, Roman E, Rollinson S, Cartwright RA and Morgan G: Polymorphisms in the methylenetetrahydrofolate reductase gene are associated with susceptibility to acute leukemia in adults. Proc Natl Acad Sci USA 96 : 12810-12815, 1999.

10. Guenther BD, Sheppard CA, Tran P, Rozen R, Matthews RG and Ludwig ML: The structure and properties of methylenetetrahydrofolate reductase from Escherichia coli suggest how folate ameliorates human hyperhomocysteinemia. Nat Struct Biol 6 : 359-365, 1999

11. Kang SS, Wong PW, Susmano A, Sora J, Norusis M and Ruggie N: Thermolabile methylenetetrahydrofolate reductase: An inherited risk factor for coronary artery disease. Am J Hum Genet 48: 536-545, 1991.

12. Poort SR, Rosendaal FR, Reitsma PH and Bertina RM: A common genetic variation in the 3'-untranslated region of the prothrombin gene is associated with elevated plasma prothrombin levels and an increase in venous thrombosis. Blood 88: 3698-3703, 1996.

13. Rosendaal FR, Siscovick DS, Schwartz SM, Psaty BM, Raghunathan TE and Vos HL: A common prothrombin variant $(20210 \mathrm{G}$ to $\mathrm{A})$ increases the risk of myocardial infarction in young women. Blood 90: 1747-1750, 1997.

14. Doggen CJ, Cats VM, Bertina RM and Rosendaal FR: Interaction of coagulation defects and cardiovascular risk factors: Increased risk of myocardial infarction associated with factor V Leiden or prothrombin 20210A. Circulation 97: 1037-1041, 1998.

15. Franco RF, Trip MD, ten Cate H, van den Ende A, Prins MH, Kastelein JJ and Reitsma PH: The 20210 G-->A mutation in the 3 -untranslated region of the prothrombin gene and the risk for arterial thrombotic disease. Br J Haematol 104: 50-54, 1999.

16. Ridker PM, Hennekens CH and Miletich JP: G20210A mutation in prothrombin gene and risk of myocardial infarction. Circulation 99: 999-1004, 1999.
17. Brown K, Luddington R, Williamson D, Baker $\mathrm{P}$ and Baglin T: Risk of venous thromboembolism associated with a $\mathrm{G}$ to $\mathrm{A}$ transition at position 20210 in the 3'-untranslated region of the prothrombin gene. Br J Haematol 98: 907-909, 1997.

18. Makris M, Preston FE, Beauchamp NJ, Cooper PC, Daly ME, Hampton KK, Bayliss P, Peake IR and Miller GJ: Co-inheritance of the 20210A allele of the prothrombin gene increases the risk of thrombosis in subjects with familial thrombophilia. Thromb Haemost 78: 1426-1429, 1997.

19. Arruda VR, Annichino-Bizzacchi JM, Gonçalves MS and Costa FF: Prevalence of the prothrombin gene variant (nt20210A) in venous thrombosis and arterial disease. Thromb Haemost 78: 1430-1433, 1997.

20. Miller SA, Dykes DD and Polesky HF: A simple salting out procedure for extracting DNA from human nucleated cells. Nucleic Acids Res 16: 1215, 1988.

21. FrosstP,Blom HJ,Milos R, Goyette P, SheppardCA,Matthews RG, Boers GJ, den Heijer M, Kluijtmans LA, van den Heuvel LP, et al: A candidate genetic risk factor for vascular disease: A common mutation in methylenetetrahydrofolate reductase. Nat Genet 10 : 111-113, 1995.

22. Danneberg J, Abbes AP, Bruggeman BJ, Engel H, Gerrits J and Martens A: Reliable genotyping of the G-20210-A mutation of coagulation factor II (prothrombin). Clin Chem 44: 349-351, 1998.

23. Cushman M: Hemostatic risk factors for cardiovascular disease. In: Hematology. Schechter GP, Hoffman R and Schrirer SL (eds). The American Society of Haematology, Washington, DC, pp236-242, 1999.

24. Ridker PM: Fibrinolytic and inflammatory markers for arterial occlusion: The evolving epidemiology of thrombosis and hemostasis. Thromb Haemost 78: 53-59, 1997.

25. Grant PJ: Polymorphisms of coagulation/fibrinolysis genes: Gene environment interactions and vascular risk. Prostaglandins Leukot Essent Fatty Acids 57: 473-477, 1997.

26. Di Minno G, Grandone E and Margaglione M: Clinical relevance of polymorphic markers of arterial thrombosis. Thromb Haemost 78: 462-466, 1997.

27. Jukic I, Bingulac-Popovic J, Dogic V, Hecimovic A, Babic I, Batarilo I, Maglov C and Sturm D: Evaluation of ABO blood groups as a risk factor for myocardial infarction. Blood Transfus 11: 464-465, 2013.

28. Dikmen M, Ozbabalik D, Gunes HV, Degirmenci I, Bal C, Ozdemir $G$ and Basaran A: Acute stroke in relation to homocysteine and methylenetetrahydrofolate reductase gene polymorphisms. Acta Neurol Scand 113: 307-314, 2006.

29. Girelli D, Friso S, Trabetti E, Olivieri O, Russo C, Pessotto R, Faccini G, Pignatti PF, Mazzucco A and Corrocher R: Methylenetetrahydrofolate reductase C677T mutation, plasma homocysteine, and folate in subjects from northern Italy with or without angiographically documented severe coronary atherosclerotic disease: Evidence for an important genetic-environmental interaction. Blood 91: 4158-4163, 1998.

30. Klerk M, VerhoefP,Clarke R,Blom HJ,KOK FJ, Schouten EG, et al: MTHFR $677 \mathrm{C}-->\mathrm{T}$ polymorphism and risk of coronary heart disease: a meta-analysis. JAMA 288: 2023-2031, 2002.

31. Akar N, Akar E, Akçay R, Avcu F, Yalcin A and Cin S: Effect of methylenetetrahydrofolate reductase 677 C-T, 1298 A-C, and $1317 \mathrm{~T}-\mathrm{C}$ on factor V 1691 mutation in Turkish deep vein thrombosis patients. Thromb Res 97: 163-167, 2000.

32. Spiroski I, Kedev S, Antov T, Krstevska M, Dzhekova-Stojkova S, Kostovska S, Trajkov D, Petlichkovski A, Strezova A, et al: Association of methylenetetrahydrofolate reductase (MTHFR-677 and MTHFR-1298) genetic polymorphisms with occlusive artery disease and deep venous thrombosis in Macedonians. Croat Med J 49: 39-49, 2008.

33. Grandone E, Corrao AM, Colaizzo D, Vecchione G, Di Girgenti C, Paladini D, Sardella L, Pellegrino M, Zelante L, Martinelli P, et al: Homocysteine metabolism in families from southern Italy with neural tube defects: Role of genetic and nutritional determinants. Prenat Diagn 26: 1-5, 2006.

34. Cesari M, Zanchetta M, Burlina A, Pedon L, Maiolino G, Sticchi D, Pessina AC and Rossi GP: Hyperhomocysteinemia is inversely related with left ventricular ejection fraction and predicts cardiovascular mortality in high-risk coronary artery disease hypertensives. Arterioscler Thromb Vasc Biol 25: 115-121, 2005.

35. Papoutsakis C, Yiannakouris N, Manios Y, Papaconstantinou E, Magkos F, Schulpis KH, Zampelas A and Matalas AL: Plasma homocysteine concentrations in Greek children are influenced by an interaction between the methylenetetrahydrofolate reductase C677T genotype and folate status. J Nutr 135: 383-388, 2005. 
36. Zuntar I, Topić E, Vukosavić D, Vuković V, Demarin V, Begonja A, Antoljak N and Simundić AM: Croatian population data for the C677T polymorphism in methylenetetrahydrofolate reductase: Frequencies in healthy and atherosclerotic study groups. Clin Chim Acta 335: 95-100, 2003

37. Xuan C, Li H, Zhao JX, Wang HW, Wang Y, Ning CP, Liu Z, Zhang BB, He GW and Lun LM: Association between MTHFR polymorphisms and congenital heart disease: A meta-analysis based on 9,329 cases and 15,076 controls. Sci Rep 4: 7311, 2014.

38. Balogh E, Bereczky Z, Katona E, Koszegi Z, Edes I, Muszbek L and Czuriga I: Interaction between homocysteine and lipoprotein(a) increases the prevalence of coronary artery disease/myocardial infarction in women: A case-control study. Thromb Res 129: 133-138, 2012.

39. Iqbal MP, Fatima T, Parveen S, Yousuf FA, Shafiq M, Mehboobali N, Khan AH, Azam I and Frossard PM: Lack of association of methylenetetrahydrofolate reductase $677 \mathrm{C}>\mathrm{T}$ mutation with coronary artery disease in a Pakistani population. J Mol Genet Med 1: 26-32, 2005.

40. Alfirevic Z, Simundic A-M, Nikolac N, Sobocan N, Alfirevic I Stefanovi M, Vucicevic Z and Topic E: Frequency of factor II G20210A, factor V Leiden, MTHFR C677T and PAI-1 5G/4G polymorphism in patients with venous thromboembolism: Croatian case-control study. Biochem Med 20: 229-235, 2010.

41. Mamasoula C, Prentice RR, Pierscionek T, Pangilinan F, Mills JL, Druschel C, Pass K, Russell MW, Hall D, Töpf A, et al: Association between C677T polymorphism of methylene tetrahydrofolate reductase and congenital heart disease: meta-analysis of 7697 cases and 13,125 controls. Circ Cardiovasc Genet 6 : 347-353, 2013

42. Keijzer MB, Borm GF, Blom HJ, Bos GM, Rosendaal FR and den Heijer M: No interaction between factor V Leiden and hyperhomocysteinemia or MTHFR 677TT genotype in venous thrombosis. Results of a meta-analysis of published studies and a large case-only study. Thromb Haemost 97: 32-37, 2007.

43. Lewis SJ, Ebrahim S and Davey Smith G: Meta-analysis of MTHFR $677 \mathrm{C}->\mathrm{T}$ polymorphism and coronary heart disease: Does totality of evidence support causal role for homocysteine and preventive potential of folate? BMJ 331: 1053, 2005.

44. Li YY: Methylenetetrahydrofolate reductase C677T gene polymorphism and coronary artery disease in a Chinese Han population: A meta-analysis. Metabolism 61: 846-852, 2012.

45. Xuan C, Bai XY, Gao G, Yang Q and He GW: Association between polymorphism of methylenetetrahydrofolate reductase (MTHFR) C677T and risk of myocardial infarction: A meta-analysis for 8,140 cases and 10,522 controls. Arch Med Res 42: 677-685, 2011.
46. Lane DA, Philippou H and Huntington JA: Directing thrombin. Blood 106: 2605-2612, 2005.

47. Kapur RK, Mills LA, Spitzer SG and Hultin MB: A prothrombin gene mutation is significantly associated with venous thrombosis. Arterioscler Thromb Vasc Biol 17: 2875-2879, 1997.

48. Ercan B, Tamer L, Sucu N, Pekdemir H, Camsari A and Atik U: Factor VLeiden and prothrombin G20210A gene polymorphisms in patients with coronary artery disease. Yonsei Med J 49: 237-243, 2008

49. Gohil R, Peck G and Sharma P: The genetics of venous thromboembolism. A meta-analysis involving approximately 120,000 cases and 180,000 controls. Thromb Haemost 102: 360-370, 2009.

50. Watzke HH, Schüttrumpf J, Graf S, Huber K and Panzer S: Increased prevalence of a polymorphism in the gene coding for human prothrombin in patients with coronary heart disease. Thromb Res 87: 521-526, 1997.

51. Ferraresi P, Marchetti G, Legnani C, Cavallari E, Castoldi E, Mascoli F, Ardissino D, Palareti G and Bernardi F: The heterozygous $20210 \mathrm{G} / \mathrm{A}$ prothrombin genotype is associated with early venous thrombosis in inherited thrombophilias and is not increased in frequency in artery disease. Arterioscler Thromb Vasc Biol 17: 2418-2422, 1997.

52. Corral J, Gonzalez-Conejero R, Lozano ML, Rivera J, Heras I and Vicente V: The venous thrombosis risk factor $20210 \mathrm{~A}$ allele of the prothrombin gene is not a major risk factor for arterial thrombotic disease. Br J Haematol 99: 304-307, 1997.

53. Ridker PM, Hennekens CH and Miletich JP: G20210A mutation in prothrombin gene and risk of myocardial infarction, stroke, and venous thrombosis in a large cohort of US men. Circulation 99: 999-1004, 1999.

54. Makris TK, Krespi PG, Hatzizacharias AN, Gialeraki AE, Anastasiadis G, Triposkiadis FK, Mandalaki $T$ and Kyriakidis MK: Resistance to activated protein $\mathrm{C}$ and $\mathrm{FV}$ leiden mutation in patients with a history of acute myocardial infarction or primary hypertension. Am J Hypertens 13: 61-65, 2000.

55. Burzotta F, Paciaroni K, De Stefano V, Chiusolo P, Manzoli A, Casorelli I, Leone AM, Rossi E, Leone G, Maseri A, et al: Increased prevalence of the G20210A prothrombin gene variant in acute coronary syndromes without metabolic or acquired risk factors or with limited extent of disease. Eur Heart J 23: 26-30, 2002. 